Synthesis Alerts is a monthly feature to help readers of Synthesis keep abreast of new reagents, catalysts, ligands, chiral auxiliaries, and protecting groups which have appeared in the recent literature. Emphasis is placed on new developments but established reagents, catalysts etc are also covered if they are used in novel and useful reactions. In each abstract, a specific example of a transformation is given in a concise format designed to aid visual retrieval of information.

Synthesis Alerts is a personal selection by:

Fabrize Anizon, Robert Chow, Marcel de Puit and Sukhjinder Uppal, Departmetn of Chemistry, Leeds University, Leeds, LS2 9JT, UK.

Georg Thieme Verlag does not accept responsibility for the accuracy, content, or selection of the data.

Synthesis 2001, No. 10, 3007 2001. Article Identifier: 1437-210X,E;2001,0,10,1579,1583,ftx,en;X01001SS.pdf.

(C) Georg Thieme Verlag Stuttgart · New York

ISSN 0039-7881
The journals regularly covered by the abstractors are:

Angewandte Chemie International Edition

Bulletin of the Chemical Society of Japan

Chemical Communications

Chemistry A European Journal

Chemistry Letters

Collection Czechoslovak Chemical Communications

European Journal of Organic Chemistry

Helvetica Chimica Acta

Heterocycles

Journal of the American Chemical Society

Journal of Organic Chemistry

Organic Letters

Organometallics

Perkin Transactions I

Synlett

Synthesis

Tetrahedron

Tetrahedron Asymmetry and Tetrahedron Letters

\begin{tabular}{l}
\hline Gallium(III) Trifluoromethanesulfonate \\
$\begin{array}{l}\text { The title reagent promotes the Friedel- } \\
\text { Crafts acylation of aniline derivatives. }\end{array}$ \\
$\begin{array}{l}\text { Kobayashi, S.; Komoto, I.; Matsuo, J. } \\
\text { Adv. Synth. Catal. 2001, 343, 71. }\end{array}$ \\
$\begin{array}{l}\text { Scandium Tris(dodecylsulfate) } \\
\text { The title reagent promotes the } \\
\text { conjugate addition of indoles to } \\
\text { electron-deficient olefins in water. }\end{array}$ \\
$\begin{array}{l}\text { Manabe, K.; Aoyama, } \mathrm{N} . ; \text { Kobayashi, } \\
\text { S. Adv. Synth. Catal. 2001, 343, 175. }\end{array}$
\end{tabular}

Reagent A catalyses olefin metathesis for the enantioselective synthesis of unsaturated cyclic tertiary ethers.

Cefalo, D. R.; Kiely, A. F.; Wuchrer, M.; Jamieson, J. Y.; Schrock, R. R.; Hoveyda, A. H. J. Am. Chem. Soc. 2001, 123, 3139.

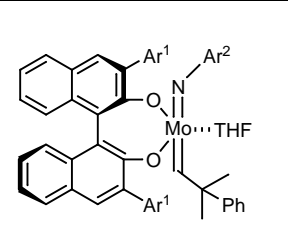<smiles>C=CCOC1(C2CCCC2)CC=CC1</smiles>
$\underset{\mathrm{PhH}, 50^{\circ} \mathrm{C}, 4 \mathrm{~h}}{\stackrel{\mathrm{A}(5 \mathrm{~mol} \%)}{\longrightarrow}}$

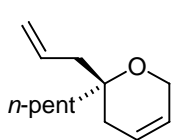

5 examples (yields 73-95\%, \%ee 74-96\%). 
The title catalyst is used for the one-pot tandem Pd-catalysed hydrostannylation/Stille coupling protocol for the stereoselective generation of vinyltins and their subsequent union.

Gallagher, W. P.; Terstiege, I.; Maleczka, R. E. Jr. J. Am. Chem. Soc. 2001, 123, 3194 .

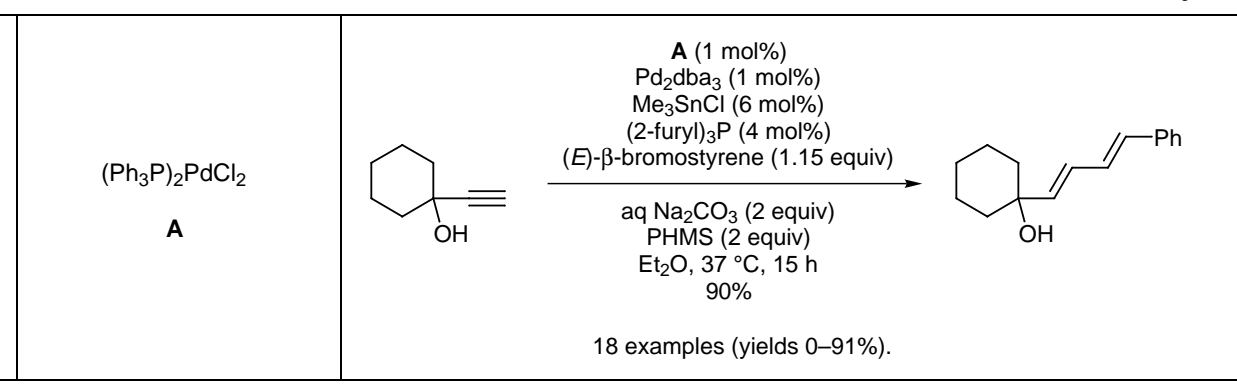

\section{Thiolate-bridged Diruthenium Complex}

Catalyst

Reagent $A$ promotes the alkylation of propargylic alcohols with ketones to afford $\gamma$-keto acetylenes.

Nishibayashi, Y.; Wakiji, I.; Ishii, Y.; Uemura, S.; Hidai, M. J. Am. Chem. Soc. 2001, 123, 3393.

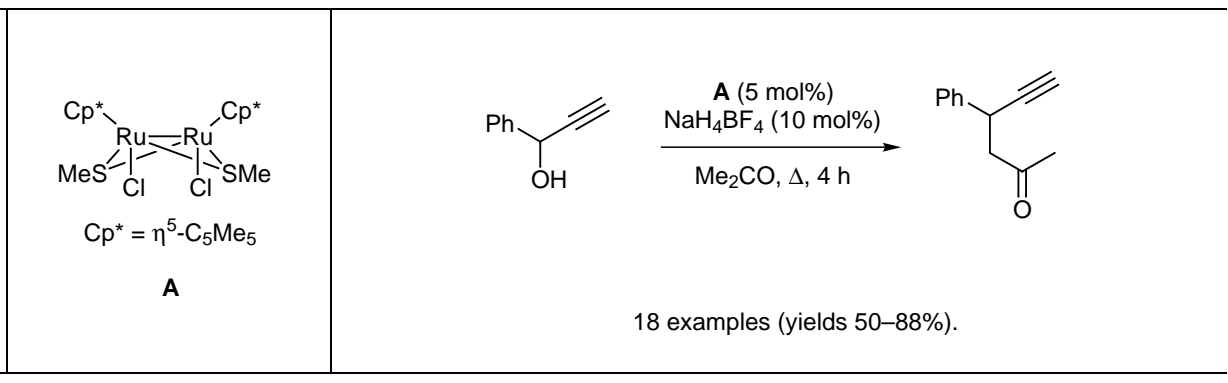

Trost, B. M.; Lee, C. B. J. Am. Chem. Soc. 2001, 123, 3671 .
$\pi$-Allylpalladium Chloride Dimer/Chiral Phosphine Ligand

Catalyst

The title reagent pair promotes the asymmetric addition of malonate nucleophiles to geminal dicarboxylates.

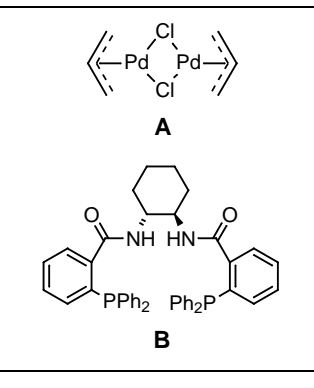

\section{Chiral Tridentate Oxovanadium(IV) Complex}

The title reagent catalyses the asymmetric oxidative coupling of various 3-, 6-, and 7-substituted 2napthols under oxygen to afford BINOLs.

Hon, S.-W.; Li, C-H.; Kuo, J.-H.; Barhate, N. B.; Liu, Y.-H.; Wang, Y.; Chen, C.-T. Org. Lett. 2001, 3, 869.

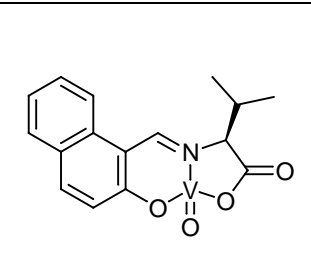

A<smiles>Oc1ccc2ccccc2c1</smiles>

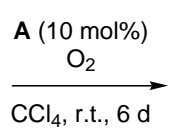<smiles>Oc1ccc2ccccc2c1-c1c(O)ccc2ccccc12</smiles>

7 examples (yields $75-100 \%$, \%ee 35-68\%).

\section{Platinum(0)-1,3-divinyl-1,1,3,3-tetramethyldisiloxane [Pt(DVDS)] -Tris(tert-butyl)phosphine Complex}

The title reagent catalyses the hydrosilylation of terminal alkynes to give disiloxanes, which then undergo palladium-catalysed cross-coupling with aryl and alkenyl iodides to afford the corresponding alkenes.

Denmark, S. E.; Wang, Z. Org. Lett. 2001, 3, 1073. (a) $\mathbf{A}$ ( 0.8 equiv) $\left(\mathrm{HMe}_{2} \mathrm{Si}\right)_{2} \mathrm{O}$ (1 equiv) THF, r.t., $30 \mathrm{~min}$

(b) 2 -(MeO) $\mathrm{C}_{6} \mathrm{H}_{4} \mathrm{l}$ (0.8 equiv) $n-\mathrm{C}_{5} \mathrm{H}_{11}$ $\mathrm{Pd}(\mathrm{dba})_{2}(5 \mathrm{~mol} \%)$ TBAF ( 1.5 equiv) THF, r.t., $10 \mathrm{~min}$ 
The title reagent pair catalyses the Suzuki-Miyaura cross-coupling of aryl halides with arylboronic acids.

Grasa, G. A.; Hillier, A. C.; Nolan, S. P. Org. Lett. 2001, 3, 1077.

$\mathrm{Pd}(\mathrm{OAc})_{2}$
B

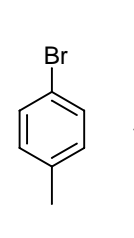

A (3 mol\%), B (3 mol\%)

$\mathrm{Cs}_{2} \mathrm{CO}_{3}$ (2 equiv)

$\mathrm{PhB}(\mathrm{OH})_{2}(1.5$ equiv)

dioxane, $80{ }^{\circ} \mathrm{C}, 3 \mathrm{~h}$

$99 \%$

18 examples (yields 20-99\%) are reported.

\section{Nickel Bis(diphenylphosphanyl)ethane Dibromide}

Catalyst

The title reagent catalyses the regioand stereoselective cyclisation of oxanorbornenes with alkyl propiolates.

Rayabarapu, D. K.; Sambaiah, T.; Cheng, C. -H. Angew. Chem. Int. Ed. 2001, 40, 1286.

[NiBr 2 (dppe)] 15 examples (yields $56-89 \%)$ are reported.

\section{Tetrakis(triphenylphosphine)palladium}

The title reagent catalyses the [3+2] cycloaddition of alkylidene-

cyclopropanes with aldehydes.

Nakamura, I.; Oh, B. H.; Saito, S.; Yamamoto, Y. Angew. Chem. Int. Ed. 2001, 40, 1298.

\section{Vanadyl Acetylacetonate}

The title reagent catalyses the selective oxidation of olefins to vicinal syn-diols by aqueous hydrogen peroxide, osmium tetroxide and $\mathrm{N}$ methylmorpholine (NMM).

Ell, A. H.; Jonsson, S. Y.; Börje, A.; Adolfsson, H.; Bäckvall, J.-E. Tetrahedron Lett. 2001, 42, 2569.

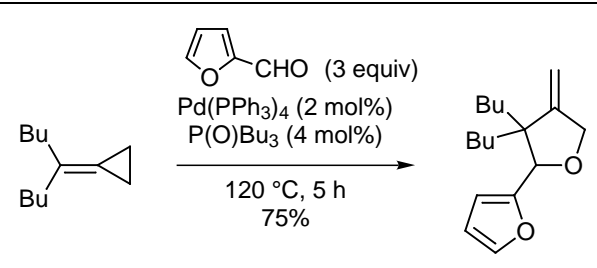

10 examples (yields 38-86\%).
The title ligand is used in the asymmetric ruthenium-catalysed hydrogenation of various carbonyl compounds.

Saito, T.; Yokozawa, T.; Ishizaki, T.; Moroi, T.; Sayo, N.; Miura, T.; Kumobayashi, H. Adv. Synth. Catal. 2001, 343, 264.

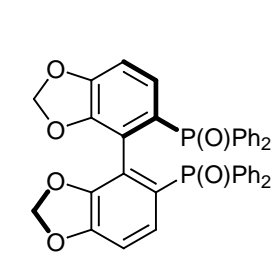

A<smiles>CC(=O)CO</smiles>

$\underset{\mathrm{MeOH}, 65^{\circ} \mathrm{C}, 7 \mathrm{~h}}{\stackrel{\text { A }(0.01 \mathrm{~mol} \%)}{\mathrm{H}_{2}\left(30 \mathrm{~kg} / \mathrm{cm}^{2}\right)}}$<smiles>CC(O)CO</smiles>

$100 \%$

7 examples (yields $99-100 \%$, \%ee 93-99\%). 
Ligand $\mathrm{A}$ is used in combination with diethylzinc to promote the asymmetric aldol reaction.

Trost, B. M.; Ito, H.; Silcoff, E. R. J. Am. Chem. Soc. 2001, 123, 3367.

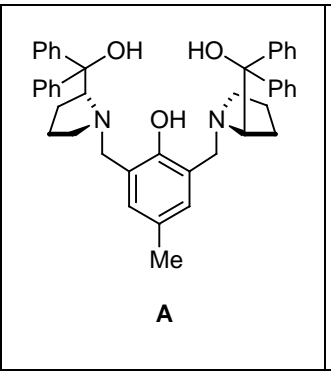

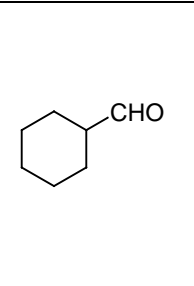

10 examples (yields $62-97 \%$, \%de $50-100 \%$, \%ee $81-98 \%$ ).

The title ligand is used for the rhodiumcatalysed enantioselective hydroboration of styrene derivatives.

Demay, S.; Volant, F.; Knochel, P. Angew. Chem. Int. Ed. 2001, 40, 1235.

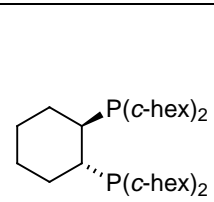

A

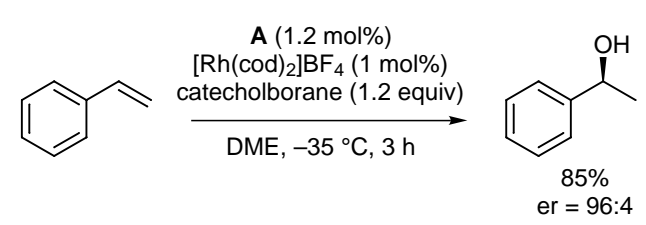

10 examples (yields 50-85\%, \%ee 58-93\%).

\section{Bisoxazoline Ligand}

Ligand

The title ligand is used for conjugate radical addition to dehydroalanines followed by enantioselective $\mathrm{H}$-atom transfer.

Sibi, M. P.; Asano, Y.; Sausker, J. B. Angew. Chem. Int. Ed. 2001, 40, 1293.

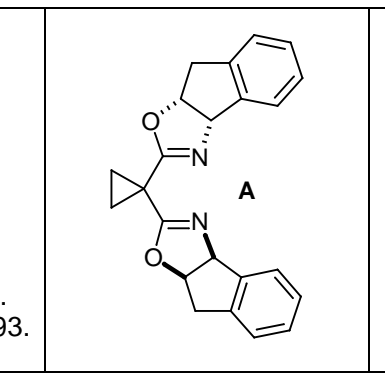

$$
\text { 2-naph }
$$

\section{Arduengo-type Stabilised Carbene}

The title reagent accelerates the copper-catalysed conjugate addition of diethylzinc to enones.

Fraser, P. K.; Woodward, S.

Tetrahedron Lett. 2001, 42, 2747.<smiles>O=C1C=CCCC1</smiles>

\section{A $(5 \mathrm{~mol} \%)$}

$\mathrm{Cu}(\mathrm{OTf})_{2}(4.5 \mathrm{~mol} \%)$

THF-PhMe (1:1), $-20^{\circ} \mathrm{C}, 30 \mathrm{~min}$ $100 \%$

\section{Menthyl Binaphthylphosphite}

The title reagent is used in the rhodium-catalysed enantioselective hydrogenation of prochiral olefins.

Chen, W.; Xiao, J. Tetrahedron Lett. 2001, 42, 2897.
A

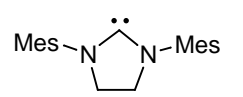

A $(0.1 \mathrm{~mol} \%)$

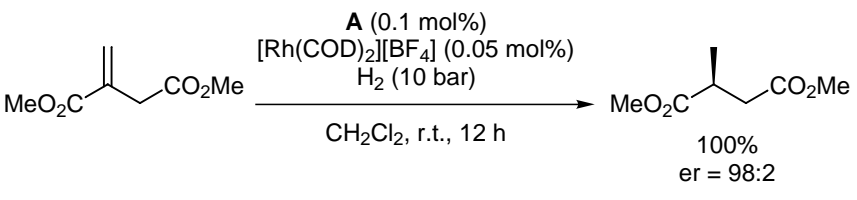

A

2 examples (yields 100\%, \%ee 75-96\%). 
The title reagent is used for the triethylborane-induced radical reaction of halogeno acetals bearing an allyl moiety.

Nicolaou, K. C.; Baran, P. S. Zhong Y-L. J. Am. Chem. Soc. 2001, 123, 3183.

\section{O-lodoxybenzoic Acid (IBX)}

The title reagent promotes the selective oxidation at carbon adjacent to aromatic systems.

Fujita, K.; Nakamura, T.; Yorimitsu, H Oshima K. J. Am. Chem. Soc. 2001,

\section{Chlorodicyclohexylborane}

The title reagent, in the presence of a tertiary amine, is used in the asymmetric boron aldol additions of $O$ protected $\alpha, \alpha^{\prime}$-dioxygenated ketones.

Murga, J.; Falomir, E.; Carda, M. González, F.; Marco, J. A. Org. Lett. 2001, 3, 901 .

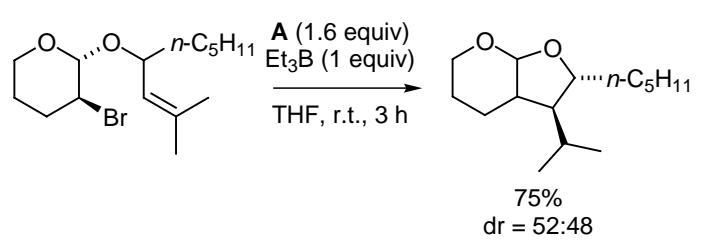

13 examples (yields 46-94\%, \%de 2-64\%).
$\mathrm{Cp}_{2} \mathrm{Zr}(\mathrm{H}) \mathrm{Cl}$

A

\begin{tabular}{l|l|l}
\hline \multicolumn{2}{l|}{ Samarium Diiodide } & \\
\hline $\begin{array}{l}\text { The title reagent induces } \beta \text {-elimination } \\
\text { of O-acetyl 1-chloro-1-trimethyl- } \\
\text { silylalkan-2-ols to afford (Z)- } \\
\text { vinylsilanes. }\end{array}$ & & \\
Concellón, J. M.; Bernad, P. L.; \\
Bardales, E. Org. Lett. 2001, 3,937.
\end{tabular}

\section{Tetrakis(triphenylphosphine)palladium(0)/Zinc Chloride}

The title reagent pair is used in
combination with polymethyl-
hydrosiloxane (PMHS) for the selective
cleavage of allyl ethers, amines and
esters.
Chandrasekhar, S.; Raji, Reddy C.;
Jagadeeshwar, Rao R. Tetrahedron
2001, 57, 3435.

